\title{
DION BOUCICAULT'S ROBERT EMMET?: THE QUESTION OF AUTHORSHIP AND THE SEASON PREMIERE AT THE MCVICKER'S THEATRE, CHICAGO, ON NOVEMBER 5, 1884.
}

\author{
Fernanda Korovsky Moura ${ }^{1^{\times}}$
}

${ }^{1}$ Universidade Federal de Santa Catarina, Florianópolis, SC, Brasil

\begin{abstract}
The Irish playwright Dion Boucicault (1820-1890) spent most of his career in the United States, where he established himself, adapting crucial moments of Irish history to the stage. Robert Emmet (1884), a play produced at the end of his career, arouses questioning surrounding its authorship. The dramatic text was arguably written by the playwright Frank Marshall (1840-1889) at the request of the actor Henry Irving (18381905). This article explores the question of Robert Emmet's authorship and investigates the reception of the production in its unsuccessful opening season at the McVicker's Theatre in Chicago in November, 1884, and Boucicault's part in it.

Keywords: Dion Boucicault; Robert Emmet; Authorship; McVicker's Theatre; Chicago
\end{abstract}

"Doutoranda do Programa de Pós-Graduação em Inglês: Estudos Linguísticos e Literários da Universidade Federal de Santa Catarina (UFSC) em cotutela com a Universidade de Leiden, na Holanda, onde atua como Professora Assistente na área de estudos literários. E-mail: f.k.moura@hum.leidenuniv.nl. ORCID: https:// orcid.org/0000-0002-2384-5255. 
Dionysius Boursiquot, better known as Dion Boucicault (1820-1890), the renowned Irish playwright, actor and theatre manager whose work transcended the Irish stage to the other side of the Atlantic, spent a big part of his life living and working in the United States, becoming an American citizen in 1873 (Howes 2011, 84). Marjorie Howes (2011) affirms that he "was arguably the most famous and influential man of the theater in the Anglophone Atlantic world between 1840 and 1880" (84). Although Boucicault spent most of his career working in international lands, it was his triptych of Irish plays that granted him notoriety: The Colleen Bawn (1860), Arrah-na-Pogue (1864) and The Shaughraun (1874), which were published in the single volume The Dolmen Boucicault in 1964. As Deirdre McFeely (2012) points out, "in the introduction to the volume, David Krause observed that Boucicault was by then [1964] 'a forgotten and much maligned figure,' and he noted that none of his works had survived in the modern repertoire" $(2012,1)$. Indeed, Townsend Walsh writes in The Career of Dion Boucicault (2013) that he "never felt himself outmoded. Younger men with fresher ideas and nervous enthusiasm pressed forward, but he never said 'Cedo junioribus"' (160). Nevertheless, in the last decades of the nineteenth century, Boucicault realised that "he had outlived his popularity" (Walsh 160-161), struggling to find original and captivating ideas for new productions. The Dolmen Boucicault, therefore, played an important role in bringing the playwright and his works back to the spotlight in the middle of the twentieth century, and in igniting academic interest in him.

One of Boucicault's greatest achievements in theatre was the re-evaluation of the stage Irishman, which had generally been caricaturedly represented as a boisterous and buffoon character. In a review of the opening night of Arrah-naPogue in 1864, the Irish Times wrote about the importance of Irish characterisation in Boucicault:

[...] never was a country better abused by strangers than Ireland by its own dramatists. With the best and most abundant material for a true picture of national life and manners, they contented themselves with the success that is to be obtained by raising a laugh at the expense of their country. It is to their production and not to the injustice of strangers, that we owe the disparaging estimate of the Celt which, until recently, prevailed in England. A thing of rags and tatters, of blunders and mischief-making, of noise and absurdity - a compound at best of rollicking good nature, impracticable obstinacy and effervescent courage, was the stage Irishman. If Mr Dion Boucicault did no other service, he rectified this ridiculously false impression of Irish character, and upon The Colleen Bawn he may fairly found a claim to the gratitude and support of Dublin playgoers. (McFeely 33)

Arrah-na-Pogue is a drama set in the Irish rebellion of 1798 against British rule in Ireland. This article, however, focuses on Robert Emmet (1884), an endeavour at bringing Ireland and its cultural heritage back to the spotlight: a play set in 1803, another moment of rebellion in Irish history, this time led by the nationalist Robert Emmet (1778-1803). The present article focuses on the question of authorship 
surrounding the creation of the play in the second half of the nineteenth century and aims at investigating the reception of the production in its opening season at the McVicker's Theatre in Chicago in November, 1884.

\section{Boucicault's Robert Emmet? - The Question of Authorship}

Boucicault's theatrical work is closely linked to melodrama. Howes in her study of The Octoroon, The Colleen Bawn and The Shaughraun identifies that Boucicault's melodramas relate specifically to issues of race, ethnicities, and geographical consciousness. However, history also becomes a source for sensationalism, especially in Robert Emmet. Boucicault managed to insert historical enquiry in his melodramatic pieces, inviting the audience to see for themselves pieces of Irish history on stage. According to Stephen Watt (1991), "although they [the Irish triptych] were certainly devised to entertain, these plays and their Irish characters reflect his increased awareness of Irish history and contemporary political tensions... his nationalist sympathies grew in intensity, leading to his brief historical essay A Fireside Story of Ireland and later to his tragic historical drama Robert Emmet" $(1991,56)$, which was one of his last works in the theatre.

There is a great discussion, however, as to the extent of Boucicault's participation in the writing of Robert Emmet. McFeely states that "he was essentially not the main author of Robert Emmet" (139). Bram Stoker (18471912), the secretary and close friend of the actor Henry Irving (1838-1905), wrote in his Personal Reminiscences of Henry Irving that throughout the latter's period in theatre management, he purchased twenty-seven plays which could not reach the stage for various reasons: some never went past the scenario phase, others were censored, others were not delivered at all, and one was sold to another manager (Stoker 132).

Stoker (2013) stated that it had often been suggested to the actor in Ireland or by people that he should play Robert Emmet on stage, especially due to his physical similarities with the early-nineteenth-century Irish nationalist. Irving was delighted with the idea and shared it with the playwright Frank Marshall (1840-1889), who started writing the play. The text was supposed to be staged soon, the scenario was almost complete, and Irving even announced it as forthcoming. However, due to Irving's success with his productions of Shakespeare's The Merchant of Venice and Romeo and Juliet, Robert Emmet was postponed twice. Furthermore, when the Lord Chamberlain's office heard of the play, he banned its continuation. As Stoker wrote:

when that time [for the play to be staged] came the Irish question was acute. Fenianism or certain of its sequelex became recrudescent. The government of the day considered that so marked and romantic a character as Robert Emmett [sic], and with such political views portrayed so forcibly and so picturesquely as would be the case with Irving, might have a dangerous effect on a people seething in revolt. (Stoker 2013, 133-134) 
Walsh adds that "the troubled period of the Land League and agrarian violence had set in, Ireland was in a political turmoil, and an Irish play with so patriotic a figure as Emmet for its hero, and so potential an actor as Irving to incarnate Emmet, might cause untold 'ructions'" (Walsh 164).

Stoker explained that, since the play was not in a good moment for production, he let Boucicault have it when it was completed. Interestingly, Stoker affirmed that "He [Boucicault] did not, I think, improve it. Boucicault played it himself in America, but without much success" (136). His premiere at the McVicker's Theatre in Chicago in 1884 was indeed a failure, as the next part of the present article demonstrates.

Agreeing with Stoker, McFeely concludes in her study that Marshall's completed version of the play was given to Boucicault in 1884. There are manuscripts with notes by Boucicault, that show he worked on editing the dramatic text. However, "while extensive, the work in Boucicault's hand amounts to not much more than a repeatedly revised opening scene that bears no resemblance to the play as later performed, and it certainly does not suggest a playwright in full command of his material" (McFeely 170). When Boucicault premiered the play in Chicago in November 1884, he did not acknowledge Marshall's part in its creation.

\section{The Season Premiere at the McVicker's Theatre}

Before going back to 5 November, 1884, it is important to emphasise that the analysis of theatrical productions is a reconstructive task, whether they were performed recently or centuries ago. As José Roberto O'Shea (2013) explains, any live production "vanishes" once it is over; "therefore, whether or not having witnessed the performance, the analyst engages in and mediates the critical reconstruction, and the analytical procedures and constraints of the practice equally apply to seen and unseen productions" $(2013,8)$. Since theatre is an ephemeral activity, O'Shea explains that the analyst "must settle for a mediated and abstract relationship with the analysed object and seek to restore some of its main principles and effects, not ever the event itself" (9). The Robert Emmet Chicago premiere is accordingly irretrievable. Nonetheless, it is possible to critically interpret the theatrical event based on the study of secondary sources. My main interest in this research was with the reception of the opening season of Robert Emmet at the McVicker's Theatre. Therefore, I have looked into newspaper archives and theatrical reviews of the period in question.

As mentioned earlier, the premiere in Chicago was a failure. Richard Fawkes (1979) points out that the opening night was also the election day of President Grover Cleveland, which could be one of the reasons for the "poor house" (Fawkes 1979, 223). The announcement of the production in the Chicago Tribune of November 3, 1884, two days before the premiere, ascertained that "Tuesday evening Mr. McVicker will personally announce the election returns from the stage. Wednesday will be produced, for the first time on any stage, a new, original 
play by Mr. Boucicault, entitled Robert Emmet", which suggests that the election took place on the night before and not on the opening night of the play. Walsh (2013) writes that "a more inopportune time for the trial of any play could not have been chosen", since "the next President of the United States was a matter of timelier import than the tragedy of Robert Emmet" (2013, 164-165).

In a letter to Henry Irving, Boucicault wrote as follows:

I produced Emmet here last night, with emphatic success, more emphatic I thought than hearty - and when I said as much I was told that the audience were disappointed that I did not play the conspicuous character in the play - and this tempered their enthusiasm. But such a group of mishaps I never witnessed - scenes bitched - properties forgotten - supers entered on scenes where they were not wanted and were absent when they were required - guns that would not go off - oh Lord! Still we overcame it all the waits between the acts were 25 and 30 minutes long - not to speak of 3 or 4 minutes between scenes! It was awful. (qtd. in Fawkes 223)

Boucicault's letter illustrates his disappointment with the overall outcome of the production and how the crew was unprepared for such an endeavor.

According to McFeely, the Chicago Daily Tribune wrote that "the main reason for the play's lack of success was 'its sombre tone, which from the nature of the subject was hardly avoidable. Boucicault is a master of popular melodrama, but in this instance he fell between the two stools of melodrama and tragedy"' (McFeely 170). McFeely sees this as another reason to testify Marshall's authorship, since the part of Emmet was supposed to be played by Irving, an eminent tragedian. Boucicault, on the contrary, had more abilities as a comic actor. In 1884, he was already sixty-four years old and decided to play the part of Michael Dwyer (McFeely 170). His choice was not acclaimed by the critics: "given that he was admired as a comic actor, it was found to be incongruous that the character he played carried out a 'cold-blooded killing'. Had Boucicault completely rewritten the play for Chicago, he would have attempted to create a suitable role for himself as at that stage in his career audiences were coming to see him rather than his plays" (McFeely 171). A critic who attended the play wrote that "there are some bright retorts, quips, and turns, and some drollery, but real comedy there is none" (The Inter Ocean, November 6, 1884). For instance, when Quigley, his earlier follower but now disguised traitor, was outside Mr. Curran's house holding Major Sirr's horse who had arrived to arrest Emmet, and Robert managed to escape the house and saw Quigley with a horse, the rebel naively thought the man was holding the horse ready for his escape: "Quigley, you saved my life! That horse you held ready for me at the door was a godsend!" (Parkin, 1987, 340-341), when the audience would have known that Quigley's reason for being there was the complete opposite of saving Robert.

Robert Emmet was played by Joseph Haworth (1855-1903), an important American actor who was at the beginning of his career at the time. Interestingly, the website dedicated to Haworth's theatrical trajectory writes that Boucicault wrote 
the play Robert Emmet with Joe in mind for the leading character (Culliton 1), contradicting McFeely's strong arguments in the opposite direction. The production did not receive favourable reviews, as we have seen, but Joe's performance did. The Fort Wayne Journal-Gazette from October 26, 1884, announced that Haworth was in high demand at the moment: "Joseph Haworth, formerly of the Boston Museum company, and for two seasons leading man of McCullough's company, seems to be in demand, for it is reported that Brooks \& Dickson want him as leading man of Ristori's company; Tom Keene has offered him the same position with his [company], and Dion Boucicault has offered him the title role of his new play, 'Robert Emmet"' (The Fort Wayne Journal-Gazette from October 26, 1884). Walsh adds that Boucicault offered the part to another actor, Charles Coghlan (1842-1899), but when the actor read the play and "found out that Boucicault intended to bring the curtain down on Emmet standing before a file of soldiers to be shot, instead of mounting the scaffold to be hung, he refused. He deemed it an artistic mistake as well as a perversion of historical fact" (Walsh 165). It is not clear, however, if this alteration was made by Boucicault or if it was in Marshall's original text. In the published version of the play text, the stage directions are as follows: after saying, "God bless my country!", Emmet "drops the cravat [which he had removed from himself along with his coat]; a volley is heard; he falls on his knees, his hand on his heart; the shots strike the wall, and show where they have scarred the masonry. Small clouds of dust fall to the ground. The black flag is raised. Bell tolls. Stage dark" (Parkin 397). Indeed, the play ends with Emmet's execution by a rifle shot, when in reality he was hung on Thomas Street in Dublin on September 20,1803 , as the lithograph by F. W. Byrne from 1877 famously illustrates.

The Inter Ocean from 6 November, 1884, a Chicago newspaper, reviewed the opening night as follows:

In the tragic drama of 'Robert Emmet', the first production of which on any stage occurred at McVicker's Theater last evening, Mr. Boucicault has given us the most vigorous, eloquent, and elegant dialogue, the choicest diction, and chiefest literary excellence to be found in the seven score plays sprung from his prolific genius. Though we miss the spontaneity of humor, the graceful readiness of wit, and the dramatic cleverness that are the elements of charm and essence of delight in the several plays that have enjoyed greatest vitality and longest popularity, there is a compensating increase of romantic interest, of heroic spirit, of noble sentiment, and lofty purposes. The new work traverses a higher plane of emotion, has a purer motive, and a more inspiring character than most of the Boucicault plays familiar to the public; and if it fails to create an equal sympathy in general esteem with such peculiarly captivating pictures of Irish life as "The Coleen Bawn" and "The Shaughraun", it must win for its author a better regard through the intelligent judgment of those who have not the good fortune to know him in even more ambitious accomplishments. (The Inter Ocean, November 6, 1884)

The main love story in the plot is that between the protagonist and Sarah Curran, the daughter of Mr. Curran, played by Helen Leigh in the opening season. The 
love between the nationalist rebel and Sarah, and the story of how he was caught because he returned to see his lover are popular tales in Irish history. Their encounter happens in the first scene of Boucicault's play. Robert comes to Mr. Curran's house wearing a long blue coat. When he tells her about his anxieties about the Rebellion plan and how he fears becoming a mere fugitive, Sarah says: "You have no fortune but my love; you cannot be bankrupt there; you have no home, but my heart; no country but my arms; how can you be a fugitive or an exile?" (Parkin 336), being this one of many sentimental exchanges between the two lovers. Soon after, Robert is arrested by Major Sirr, but manages to escape. Captain Norman Claverhouse, a British soldier who has feelings for Sarah, forgoes his love when he learns Sarah's true feelings for Robert and helps her to marry Emmet in order to save her father's reputation: “'Tis hard on me to say the words; it is verra bitter, dear. Before this night is past you must bear my rival's name" (Parkin 338), demonstrating the soldier's noble sentiment.

Moreover, The Inter Ocean critic praises Boucicault's intermingling of fact and fiction "as is compatible with writing for the stage". The critic found it "consistent, harmonious, and effective" (The Inter Ocean, November 6, 1884). In relation to the protagonist Emmet, the critic thought "Mr. Boucicault has given to his hero the splendid attributes of one who has moral courage with physical hardihood, equally brave to do or die, with a mind as capable as his soul is daring, a spirit as tender as his ambition is divine". Nonetheless, in comparison to Emmet, the minor characters - with the exception of Andy Devlin, "who, not less than Emmet himself, was a martyr to the sweet love of patriot enterprise", and performed by Dion Boucicault Jr. (1859-1929), the playwright's son, faded in the background, "not sharply outlined nor completely filled in" (The Inter Ocean, November 6, 1884). Tiney Wolfe, however, daughter of Lord Kilwarden and played by Nina Boucicault (1867-1950), Dion's daughter, confronts her father after listening to Major Sirr's plan to use Emmet's ex-followers Quigley and Finerty to help capture and execute Emmet: "You see, papa, I overheard what those men proposed. Forgive me if my heart comes to your side and pleads to stand by yours. You taught the motherless little child how to be worthy of your name and of your race. She was nursed on your breast. Let her now give you back the teachings of your love. Have no share in this infamy. Set your honest face against it" (Parkin 347-348), and succeeds in convincing him. Later on in the play, she also musters all her waning strength after her father's death to find Emmet and warn him of an eminent attack. Nevertheless, the critic in The Inter Ocean does not regard Miss Tiney's actions as self-oriented, but as complement to Emmet's own story: "They [the minor characters, including Tiney] are the embellishment, the ornament, or the revealing ministers of Emmet's destiny rather than conspicuous, independent creations to the play's necessities". Indeed, there are no plots outside Emmet's journey. The critic from The Inter Ocean from November 9, 1884, also criticised the part given to Sarah Curren: she "is too passive and non-resisting. She should have more spirit or else a larger bounty of love, either in an heroic or an impassioned way" (The Inter Ocean, November 9, 
1884). Certainly, she should act more on her behalf, but I do not believe she lacks in love affirmations, as the extract quoted in the previous paragraph illustrates. Perhaps for a late-nineteenth-century audience, accustomed to melodramatic love stories and exaggerated sentimental acting, her character lacked in emotion.

Although the The Inter Ocean review from November 6 praised the play text overall and defended the idea that "Robert Emmet will add much to the real and enduring reputation of Mr. Boucicault," it admits the failure of the opening night production:

The play was presented under great disadvantages last evening. We do not remember ever to have seen upon McVicker's stage, even on a first night, so many annoying mishaps, tedious waits and delays in open scenes. Nor were the people well up in their parts, prompting being necessary in a number of instances, and some important "business" features of the action were perplexingly omitted, as, for instance, the firing of the shot that should kill Andy Devlin. Owing to these material defects the curtain did not fall upon the last scene until 11:45 oclock, when, within favorable circumstances, the performance will end fully an hour earlier. (The Inter Ocean, November 6, 1884)

Apart from the incidents that annoyed the critics, the actors' performance was a positive aspect of the McVicker's season. As The Inter Ocean critic reviewed, "[sic] Mrs Haworth made a pronounced success of the title role, and Mr. Dion [sic] Boucicoult, Jr., gave a representation of Andy Devlin that proved him to possess in large part the fine ability of his father." Dion Boucicault Jr. was the playwright's third child and followed his steps in the theatrical career. The review from three days later also praised Joseph Haworth, who "fully realizes the character. He gives a superb performance of the part, and is the more interesting for the striking resemblance in face and figure which he bears to the ideal pictures of the great Irish patriot" (The Inter Ocean, November 9, 1884). In relation to Miss Leigh, who played Sarah Curran, the critic reported that she "plays feelingly and capably the part of Sarah Curran as it will permit." Dion Boucicault's daughter, Nina, "does prettily and very effectively the work that fails her lot, and, like her gifted and highly talented brother, shows an inheritance of dramatic worth from her highly endowed parents" (The Inter Ocean, November 9, 1884). The other minor characters "did good work": Mr. Wilkes played Major Sirr, Mrs. Barker played Ann Devlin, and Mr. Sutton played Lord Kilwarden. And Boucicault, of course, played Michael Dwyer "who has a mere whisp of character" (The Inter Ocean, November 9, 1884). Interestingly, the review also states that "many minor changes have been made since the initial representation, and these alterations will be kept up until the radical defects of the piece have been wholly or in large part overcome" (The Inter Ocean, November 9, 1884), suggesting that the failures of the opening production were still not completely overcome four days later. The production lasted for a week at the McVicker's in Chicago.

A possible reason for the incidents and mishaps of the first productions may have been the large number of sets and scene changes. According to Mc Feely, 
"the fact that Robert Emmet clearly required a large production budget suggests that its structure was Marshall's work as he would not have been restricted by budget when writing since Irving's production values at the Lyceum were very high" (170). The play is divided in four acts: the first one with three scenes, the second with five, the third with also five, and the last act with three scenes and two final tableaux. Each scene emerges in a different set, ranging from a street in Dublin, to a room inside Dublin Castle, a Gorge in the mountains near the Scalp, Ann Devlin's cottage, the interior of Father Donnelly's chapel and a prison, to name some, which would demand a high amount of work to build and for changing in between scenes, as the critics from the time have pointed out.

Apart from the incidents in the first week of performance in Chicago and the origin of the play text, Robert Emmet is a thorough dramatic enterprise that recreates the nationalist atmosphere surrounding the 1803 rising, as well as the personal relations between its hero and his lover, friends, followers, enemies and traitors, with the touch of melodrama that pleased nineteenth-century audiences - such as the overly sentimental language, a secret marriage, the fall of Emmet's papers with information about the rebellion's plans and manifesto which later reach the hands of the villain Major Sirr, Michael Dwyer's disguise as Mother Magan, and Lord Kilwarden's murder, to name but some. The ensemble - although it wanted in elaboration and rehearsal - stirred "a ringing passion of sentiment that thrill ardent natures to the unresistance of applause", in the words of The Inter Ocean review from November 6, 1884.

\section{Final Considerations}

After "journeying" to late-nineteenth-century Chicago and investigating the archives of contemporary local newspapers, it was possible to reconstruct even if partly - the opening season of Robert Emmet at the McVicker's Theatre. Based on theatrical reviews from the week of performance, it was found that Boucicault played a minor part in the play, "a mere whisp of character," upsetting the audience that went to the theatre to see the famous playwright and actor in action. At the end of his career, Boucicault opened space in his production to his daughter Nina Boucicault and his son Dion Boucicault Jr., who chose to follow their father's artistic steps. Furthermore, despite Boucicault's great experience in the theatre in the United States and abroad, the production was a combination of failures and incidents, which disappointed the critics who witnessed the performance. Boucicault himself even admitted and regretted the occurrences in a letter written to Irving and quoted above. Nonetheless, the actors' performances were praised by the newspapers, especially Haworth in the title role.

In this article I have also tackled the discussion around the authorship of the play, based on McFeely's strong arguments and Stoker's confession that the text was not written by Boucicault but given to and little altered by him. The original author of the play would be Frank Marshall, and it was meant to be staged by Henry Irving. The name of the person behind the play's creation, however, does 
not decrease its potency as historical drama, in bringing a pivotal moment of Irish history to the American stage, and Dion Boucicault's participation in realising its production in Chicago in 1884. As the critic from The Inter Ocean from November 6,1884 , interestingly wrote: "Some may term this trickery, others describe it as dramatic genius. It is evidently potent" (The Inter Ocean, November 6, 1884).

\section{References}

Culliton, Joseph. "Supporting an Irish Idol 1882-1884." The Life \& Times of Joseph Haworth, www.josephhaworth.com/supporting_an_Irish_idol.htm.

Fawkes, Richard. Dion Boucicault. Quartet Books, 1979.

Howes, Marjorie. "Melodramatic Conventions and Atlantic History in Dion Boucicault." Éire-Ireland, vol. 46, no. 3/4, 2011, pp. 84-101. https://muse.jhu.edu/ article/458539.

McFeely, Deirdre. Dion Boucicault: Irish Identity on Stage, Cambridge University Press, 2012.

O'Shea, José Roberto. "Impossibilities and Possibilities: the Challenges of Dramatic Performance Analysis". Estudos Anglo-Americanos, vol. 40, 2013, pp. 6-18.

Parkin, Andrew. Selected Plays by Dion Boucicault. The Catholic University of America Press, 1987.

Stoker, Bram. Personal Reminiscences of Henry Irving, Vol. II. Cambridge University Press, 2013.

“The Chicago Tribune." The Chicago Tribune, 3 Nov. 1884. Newspapers.com.

"The Fort Wayne Journal-Gazette." The Fort Wayne Journal-Gazette, 26 Oct. 1884. Newspapers.com.

“The Inter Ocean." The Inter Ocean, 6 Nov. 1884. Newspapers.com.

"The Inter Ocean." The Inter Ocean, 9 Nov. 1884. Newspapers.com.

Walsh, Townsend. The Career of Dion Boucicault. Hard Press, 2013.

Watt, Stephen. Joyce, O'Casey, and the Irish Popular Theater. Syracuse University Press, 1991. 